\title{
Assessing watermilfoil invasion effects on native macrophyte communities in North American lakes using a novel approach for macrophyte sampling
}

\author{
Shannon Smith*, Frithjof C. Küpper, Clare Trinder and Vasilis Louca* \\ School of Biological Sciences, University of Aberdeen, Cruickshank Building, Aberdeen AB24 3UL, UK
}

Received: 27 October 2020 / Accepted: 9 December 2020

\begin{abstract}
Aquatic invasive species are among the greatest threats to freshwater biodiversity. The aim of this study was to understand the effects of two invasive watermilfoil species (Myriophyllum heterophyllum Michx. and Myriophyllum spicatum L.) on native macrophyte communities and to assess community response to a range of invasion intensities as well as examine the influence of canopy types. We hypothesized that some communities would be more sensitive to invasion, and that some canopy species would facilitate watermilfoil presence. We used a novel approach to give better representation of the 3D aspect of the community which involved employing a modified quadrat approach to sample at two Connecticut lakes. Results show that watermilfoil invasion has a significant negative effect on native species richness. Floating canopy does not vary with invasion intensity, but submerged canopy does. One species, (Utricularia purpurea Walter), was associated with high native species richness and rarely occurred with invasive species. The results identify potential species that are disproportionally threatened by invasive species, as well as identifying invasion indicator species. The examination of canopy effects is uncommon in aquatic invasion ecology, and this study suggests that this aspect may have significant effects on resilience to invasion and overall community dynamics.
\end{abstract}

Keywords: Myriophyllum spicatum / Myriophyllum heterophyllum / ecology / freshwater / invasive species

Résumé - Évaluation des effets de l'invasion du myriophylle en épi sur les communautés de macrophytes indigènes dans les lacs d'Amérique du Nord grâce à une nouvelle approche d'échantillonnage des macrophytes. Les espèces aquatiques envahissantes sont parmi les plus grandes menaces pour la biodiversité d'eau douce. L'objectif de cette étude était de comprendre les effets de deux espèces envahissantes de myriophylle (Myriophyllum heterophyllum Michx. et Myriophyllum spicatum L.) sur les communautés de macrophytes indigènes et d'évaluer la réponse des communautés à une série d'intensités d'invasion ainsi que d'examiner l'influence des types de canopée. Nous avons émis l'hypothèse que certaines communautés seraient plus sensibles à l'invasion et que certaines espèces de la canopée faciliteraient la présence du myriophylle. Nous avons utilisé une nouvelle approche pour donner une meilleure représentation de l'aspect 3D de la communauté, ce qui a impliqué l'utilisation d'une approche de quadrat modifiée pour échantillonner deux lacs du Connecticut. Les résultats montrent que l'invasion de myriophylle en épi a un effet négatif important sur la richesse des espèces indigènes. La canopée flottante ne varie pas avec l'intensité de l'invasion, mais la canopée submergée le fait. Une espèce, (Utricularia purpurea Walter), a été associée à une grande richesse en espèces indigènes et s'est rarement retrouvée avec des espèces envahissantes. Les résultats permettent d'identifier les espèces potentielles qui sont menacées de façon disproportionnée par les espèces envahissantes, ainsi que d'identifier les espèces indicatrices d'invasion. L'examen des effets de la canopée est peu courant dans l'écologie des invasions aquatiques, et cette étude suggère que cet aspect peut avoir des effets importants sur la résilience aux invasions et sur la dynamique globale de la communauté.

Mots clés : Myriophyllum spicatum / Myriophyllum heterophyllum / écologie / eau douce / espèces envahissantes

\footnotetext{
*Corresponding author: v.louca@abdn.ac.uk; smithslhs@gmail.com
} 


\section{Introduction}

Aquatic plants produce some of the most severe biological invasions, since they are usually harder to control than terrestrial species (Les and Mehrhoff, 1999). Water milfoil invasion is a serious problem worldwide because of its impact on biodiversity, recreation, property values, and natural resources (Eiswerth et al., 2000; Pimentel et al., 2005; Havel et al., 2015). Eurasian watermilfoil (Myriophyllum spicatum L.), native to Europe, Asia, and Northern Africa (Smith and Barko, 1990), occurs globally and is considered to be the 'most invasive' aquatic species in North America (Les and Mehrhoff, 1999). Variable-leaf watermilfoil (Myriophyllum heterophyllum Michx.) is native to the South-eastern United States (Les and Mehrhoff, 1999), but has become highly invasive in parts of north America, as well as eight European countries and China (Gross et al., 2020).

Milfoil invasion is often a result of disturbance, but studies have also documented its colonization in undisturbed systems (Madsen, 1999). Lakes in temperate areas are particularly prone to milfoil invasion due to the high levels of natural disturbance from freeze-thaw, drought, storms, and other sources (Capers et al., 2007). Biotic factors such as native species density (Capers et al., 2007), presence of herbivore species (Qiu et al., 2019), and propagule pressure (Levine, 2000; Lockwood et al., 2005) potentially influence invasion resistance. Myriophyllum spicatum occurs in shallow water (1-4 m), grows quickly (Smith and Barko, 1990), is a strong light competitor, and often rapidly colonizes disturbed areas (Madsen et al., 1991). It was also found to exhibit a higher resistance to highly toxic copper $\left(\mathrm{Cu}^{2+}\right)$ than other ecologically important freshwater plants such as Stratiotes aloides L., Elodea canadensis Michx. and Lemna trisulca L., with up to $8 \%$ of total chlorophyll converted to $\mathrm{Cu}$-chlorophyll at the observed $2 \mu \mathrm{mol} \mathrm{l}^{-1}$ (Küpper et al., 1996).

Aquatic plant invasions have cascading effects on aquatic communities and common impacts include changes in nutrient load, water clarity, habitat availability, sediment load, and plant community structure (Van Donk and Otte, 1996; Gergs and Rothhaupt, 2015). Milfoil invasion has the capacity to reshape aquatic communities. In particular, Eurasian milfoil can increase community biomass (Bosch et al., 2009), increase water nutrient concentrations (Tan et al., 2018), alter light availability to other species (Smith and Barko, 1990), which in turn influences water temperature, dissolved oxygen concentration, and plant species composition (Strayer, 2010). Milfoil invasion suppresses native plant species, leading to reduction in diversity (Madsen et al., 1991; Boylen et al., 1999). Despite the well documented negative ecological impacts of invasion, some research indicates a positive impact with $M$. heterophyllum associated with high native macrophyte richness (Thum and Lennon, 2010). The majority of these studies have either investigated impacts on native species diversity, or overall diversity, but never analysed and compared both aspects of macrophyte diversity within the same study. It is currently recognised that in studies investigating impacts of invasive species, it is imperative that both aspects of species diversity are investigated separately (Bernard-Verdier and Hulme, 2015).
A major challenge in aquatic macrophyte lake sampling has been identifying and employing approaches that can effectively sample canopy as well as submerged species, but at the same time being able to differentiate the position in the water column (Madsen et al., 2007). A traditional quadrat (a frame applied from above) would collapse the forest-like submerged canopy, making observation of the plants underneath difficult (Madsen, 1999; Madsen et al., 2007; Madsen and Wersal, 2017), therefore necessitating the need for an alternative approach to macrophyte lake sampling.

This work examines macrophyte community responses to invasion and outlines species of concern, possible indicator species, and characteristics of communities at different degrees of invasion. Very importantly, it develops a new methodology for aquatic plant surveys and explores the interaction between invasion and canopy type and their effects on native species.

We hypothesized that, (1) increasing invasion intensity has a negative impact on the native as well as the total (overall) species richness, (2) native species demonstrate varied responses to increasing invasion intensity, and (3) the type of canopy influences invasion dynamics by either facilitating or hindering the process.

\section{Materials and methods}

Two small lakes in Goshen, Connecticut, USA, were surveyed in 2016. 'Lake 1' $(41.855020 \mathrm{~N},-73.256685 \mathrm{~W})$ and 'Lake 2' $(41.813904 \mathrm{~N},-73.239412 \mathrm{~W})$ are both partially residentially developed and have wooded wetland areas along the unoccupied shore. Lake 1 has a surface area of $0.17 \mathrm{~km}^{2}$ with a maximum depth of $9.14 \mathrm{~m}$, while Lake 2 is $0.27 \mathrm{~km}^{2}$ with a maximum depth of $3.35 \mathrm{~m}$ (Capers and Selsky, 2005; June-Wells and Hart, 2012). Thirty-three aquatic plant species are known to be present in Lake 1 (Sabina Perkins, personal communication, 4 March 2016). The Connecticut Agricultural Experiment Station (CAES) identified 19 aquatic plant species (CAES, 2005) in Lake 2. Both lakes have been invaded by M. spicatum, and Lake 1 additionally has M. heterophyllum present.

\subsection{Sampling method}

Sampling was conducted daily between 10:00 and 16:00 from 7 June 2016 to 6 September 2016. A novel, 3-D quadrat design (Fig. 1) was used to allow the best possible observation with minimum damage to the plant community and thus allowing the accurate recording of both the floating as well as submerged vegetation. This 3 -D quadrat consisted of a one metre long telescopic pole with a weighted anchor at the base that allowed the quadrat to be stabilised in the water. A rotating arm ( $1 \mathrm{~m}$ long) at the top allowed for the exact delineation of the $1 \mathrm{~m}$ radius area to be sampled accurately. Sampling took place along regularly spaced transects in which species' presence/absence was recorded, thus combining point-intercept and line transect methods (Madsen and Wersal, 2017). Transects were oriented perpendicular to the shore, with 2-m diameter circular quadrats (Capers et al., 2007), spaced seven metres apart centre-to-centre. Due to the difficulty of maintaining such a sampling system in field conditions 


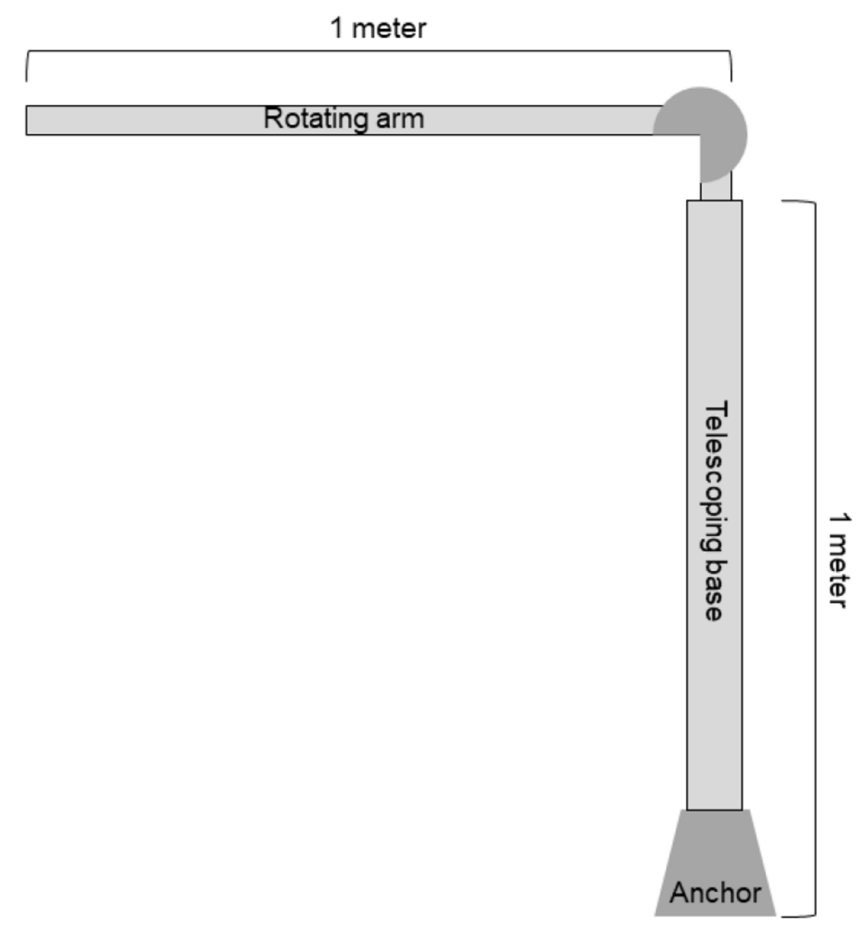

Fig. 1. Quadrat used for survey. Consists of a small anchor holding an upright PVC tube ( $1 \mathrm{~m}$ tall) with a smaller tube inside to allow the quadrat to telescope and pivot around this central axis. A $90^{\circ}$ joint connects the telescoping base to another PVC tube $(1 \mathrm{~m})$ which acts as the radius of the quadrat. Depth measurements are marked on the base to allow easy depth measurement. The anchor is a one-gallon plastic bucket filled with concrete.

(Madsen, 1999), the distance of seven metres was chosen because it could be measured with two kayak lengths. An inwater snorkelling observer recorded the data within the quadrats as described before (Capers, 2000).

\subsection{Data recording}

Quadrat number, GPS coordinates recorded with a GPS receiver, date/time, water depth, dominant floating canopy species, dominant submerged canopy species, species presence/absence, and invasion intensity was recorded. Canopy dominance was determined by estimating the percent cover of each species in the quadrat, recording the species with the most cover 'dominant'. Invasion intensity was determined by estimating percent cover of invasive species and recorded on a scale of one to five. Greater than $50 \%$ cover is categorized as invasion level five, $21-50 \%$ is four, $5-20 \%$ is three, $<5 \%$ is two, and lack of milfoil presence categorised as level one (Capers et al., 2007).

\subsection{Data analysis}

Pearson correlations discerned relationships between invasion level and water depth. Generalized linear models (hereafter, GLMs) fitted to a Poisson distribution identified factors affecting overall and native species richness in the two lakes (Capers et al., 2007). The ability of a GLM to address contributions of multiple variables while giving a significance value for each was the reason it was used for this analysis and are often used in aquatic community ecological studies (Louca et al., 2009, 2014). The Poisson distribution was selected as it provides a more appropriate model to fit the count data (in this case species richness) (Warton et al., 2016). Principal Coordinates Analysis (PCO), using the LabDSV package in R (Roberts and Roberts, 2016) was used to identify patterns or clusters of spatial association of macrophyte species. Only species that were recorded in at least 4 quadrats were included in the analysis. Since the PCO analysis used binary presence/absence data, the similarity scores reflect how often species co-occur.

Utricularia purpurea Walter and water marigold (Bidens beckii Torr. ex Spreng.) were selected in this study as focal species due to their ecological sensitivity and conservation status. B. beckii is threatened in Connecticut (Lichvar, 2012), and is listed as endangered or extirpated in other states. $U$. purpurea became a species of interest after exhibiting noteworthy relationships within this study (see Results). GLMs, with data fitted to a binary distribution (since we analysed presence/absence data), were used to analyse potential relationships between this species' presence, invasion intensity, and depth.

Chi-square tests identified whether patterns of canopy dominance changed with invasion intensity. If invasion effect was significant, we used Kruskal-Wallis tests (Stiers et al., 2011), to discern differences in species richness under each canopy. We used pairwise Mann-Whitney tests to further examine where the differences lie.

GLMs and PCO analysis were performed in R 3.6.0. Figures were produced using Microsoft Excel 2013 and Minitab 17.

\section{Results}

In total, 78 total quadrats were recorded, 63 on Lake 1 and 15 on Lake 2. A total of 33 aquatic plant species were recorded, 30 at Lake 1 (one of which was not possible to identify to species level) and 10 in Lake 2. The average sampling depth was $94.4 \mathrm{~cm}$ at Lake 1 and $103.5 \mathrm{~cm}$ at Lake 2, with an overall water depth ranging from 50 to $150 \mathrm{~cm}$. The average overall (OSR) and native species richness (NSR) at Lake 1 was 8.0 and 7.1 species, respectively. At Lake 2, OSR and NSR was 5.4 and 4.6, respectively. The highest OSR was seen at invasion level 2 (average 8.1 species) and the NSR was seen at invasion level 1 (average 7.7 species).

Correlation analysis demonstrated a positive relationship between water depth and invasion intensity $(r(76)=0.325$, $p=0.004)$. The relationship between invasion intensity and species richness is described with GLMs (Tabs. 1 and 2), taking variability due to depth and location into account in the model as covariates (Lake 1 or 2). There was a significant effect of 'lake' effect on both OSR (GLM, Odds ratio $=2.479$, $\mathrm{df}=62, p<0.001$, Tab. 1) and NSR (GLM, Odds ratio $=2.185, \mathrm{df}=62, p=0.001$, Tab. 2), which highlights macrophyte community differences between the lakes. NSR was also significantly affected by high (invasion level 5) 
Table 1. GLM results of OSR relationships with level of invasion, depth, and lake.

\begin{tabular}{lcccc}
\hline Invasion Intensity & $N$ & $\begin{array}{l}\text { Odds ratio } \\
\text { (B) }\end{array}$ & $\begin{array}{l}\text { Std. } \\
\text { Error }\end{array}$ & $P$ \\
\hline Model (intercept) & 2 & 12.034 & 1.656 & $<0.001^{*}$ \\
Invasion intensity & 78 & -0.266 & 0.222 & 0.231 \\
Depth (cm) & 78 & -0.008 & 0.016 & 0.605 \\
Lake & $63+15$ & -2.459 & 0.711 & $<0.001^{*}$ \\
\hline
\end{tabular}

${ }^{*}$ Indicates significant effects.

Table 2. GLM results of NSR relationships with level of invasion, depth, and lake.

\begin{tabular}{lcccc}
\hline Invasion intensity & $N$ & $\begin{array}{l}\text { Odds ratio } \\
\text { (B) }\end{array}$ & $\begin{array}{l}\text { Std. } \\
\text { Error }\end{array}$ & $P$ \\
\hline Model (intercept) & 2 & 11.562 & 1.656 & $<0.001^{*}$ \\
Invasion intensity & 78 & -0.526 & 0.206 & $0.001^{*}$ \\
Depth (cm) & 78 & -0.007 & 0.015 & 0.593 \\
Lake & $63+15$ & -2.459 & 0.711 & $<0.001^{*}$ \\
\hline
\end{tabular}

*Indicates significant effects.

invasion intensity (GLM, Odds ratio $=-1.909, \mathrm{df}=14$, $p=0.035)$. No significant effect of depth or species richness was found.

Principal Coordinates Analysis (PCO) was used to identify communities or species spatial associations within Lake 1 (Fig. 2). Only data from Lake 1 were used to avoid the confounding factor of location and the relatively small sample size from Lake 2. Principal Component 1 (PC1) explained 24\% of the variability in species associations, whereas PC2 explained $20 \%$ of the variability. Visually, species can be separated into 2 spatial clusters, with the cluster that includes the two invasive Myriophyllum species associated with positive PC2 values, whereas a distinct macrophyte species association which is characterised by native species is has negative PC2 values (Fig. 2).

\subsection{Floating canopy}

Four species formed the dominant floating canopy. In cases where there no floating species were present, it was recorded as 'no canopy'. Variegated pond lily (Nuphar variegata Durand) canopy was associated with the highest species richness (mean 7.8 native species, 8.7 overall species), 'no canopy' had the lowest (mean 4.6 native species, 5.5 overall species), and water shield (Brasenia schreberi J.F.Gmel.), American white waterlily (Nymphaea odorata Aiton), and broad-leaved pondweed (Potamogeton amplifolius Tuck.) had similar intermediate relationships with species richness (Fig. 3).

Chi-square tests tested differences in frequency between each dominant canopy species and invasion intensity, using the lowest invasion intensity as a baseline reference group. No differences in frequency of dominant floating canopy species
Table 3. List of all species sampled in the two lakes with average occurrence at each lake.

\begin{tabular}{|c|c|c|c|}
\hline \multirow[t]{2}{*}{ Species } & \multirow[t]{2}{*}{ Abbreviation } & \multicolumn{2}{|c|}{$\begin{array}{l}\text { Proportion of sites } \\
\text { in lake present }\end{array}$} \\
\hline & & Lake 1 & Lake 2 \\
\hline Bidens. beckii & B.bec & 0.35 & 0.00 \\
\hline Brasenia. schreberi & B.sch & 0.71 & 0.00 \\
\hline Ceratophyllum demersum & C.dem & 0.03 & 0.25 \\
\hline Chara sp. & Char. & 0.27 & 0.08 \\
\hline Eleocharis acicularis & E.ec & 0.02 & 0.00 \\
\hline Eriocaulon aquaticum & E.aq & 0.03 & 0.00 \\
\hline Elodea canadensis & E.can & 0.27 & 0.75 \\
\hline Eleocharis robbinsii & E.rob & 0.40 & 0.00 \\
\hline Heteranthera dubia & H.dub & 0.00 & 0.08 \\
\hline Myriophyllum alterniflorum & M.alt & 0.08 & 0.00 \\
\hline Myriophyllum heterophyllum & M.het & 0.73 & 0.00 \\
\hline Myriophyllum spicatum & M.spic & 0.14 & 0.92 \\
\hline Nymphoides cordata & N.cor & 0.13 & 0.00 \\
\hline Najas flexilis & N.flex & 0.32 & 0.00 \\
\hline Najas guadalupensis & N.guad & 0.00 & 0.67 \\
\hline Nymphaea odorata & N.odo & 0.86 & 0.00 \\
\hline Nymphoides variegata & N.var & 0.52 & 0.00 \\
\hline Potamogeton amplifolius & P.amp & 0.37 & 1.00 \\
\hline Potamogeton bicupulatus & P.bic & 0.17 & 0.00 \\
\hline Pontederia cordata & P.cord & 0.06 & 0.00 \\
\hline Potamogeton epihydrus & P.epi & 0.06 & 0.00 \\
\hline Potamogeton foliosus & P.fol & 0.29 & 0.00 \\
\hline Potamogeton gramineus & P.gram & 0.03 & 0.00 \\
\hline Potamogeton illinoensis & P.ill & 0.25 & 0.00 \\
\hline Potamogeton obtusifolius & P.obt & 0.05 & 0.00 \\
\hline Potamogeton robbinsii & P.rob & 0.43 & 1.00 \\
\hline Potamogeton zosteriformis & P.zos & 0.02 & 0.25 \\
\hline Sagittaria graminea & S.gram & 0.16 & 0.58 \\
\hline Scirpus sp. & Scir. & 0.08 & 0.00 \\
\hline Utricularia geminiscapa & U.gem & 0.05 & 0.00 \\
\hline Utricularia macrorhiza & U.mac & 0.02 & 0.00 \\
\hline Utricularia purpurea & U.pur & 0.70 & 0.00 \\
\hline Vallisneria americana & V.am & 0.37 & 0.00 \\
\hline
\end{tabular}

The abbreviations included here are used in Figure 2.

at no invasion compared to frequency at higher invasions was observed: [invasion level $2\left(X^{2}=1.323, \mathrm{df}=4, N=20, p=0.857\right)$, invasion level $3\left(X^{2}=2.042, \mathrm{df}=4, N=20, p=0.728\right)$, invasion level $4\left(X^{2}=7.504, \mathrm{df}=4, N=20, p=0.112\right)$, invasion level 5 $\left.\left(X^{2}=8.319, \mathrm{df}=4, N=20, p=0.081\right)\right]$.

\subsection{Submerged canopy}

Nine dominant submerged canopy (DSC) species were recognized originally. The species Eleocharis acicularis (L.) Roem \& Schult, Elodea canadensis Michx and Najas flexilis (Willd.) Rostk. \& W.L.E. Schmidt were only dominant in one quadrat, therefore they were removed from the analysis. When there was complete codominance between variable-leaf and M. spicatum, it was recorded as 'Myriophyllum'.

Chi-square tests identified a significant difference in canopy species frequency between a baseline of no invasion 
S. Smith et al.: Knowl. Manag. Aquat. Ecosyst. 2021, 422, 1

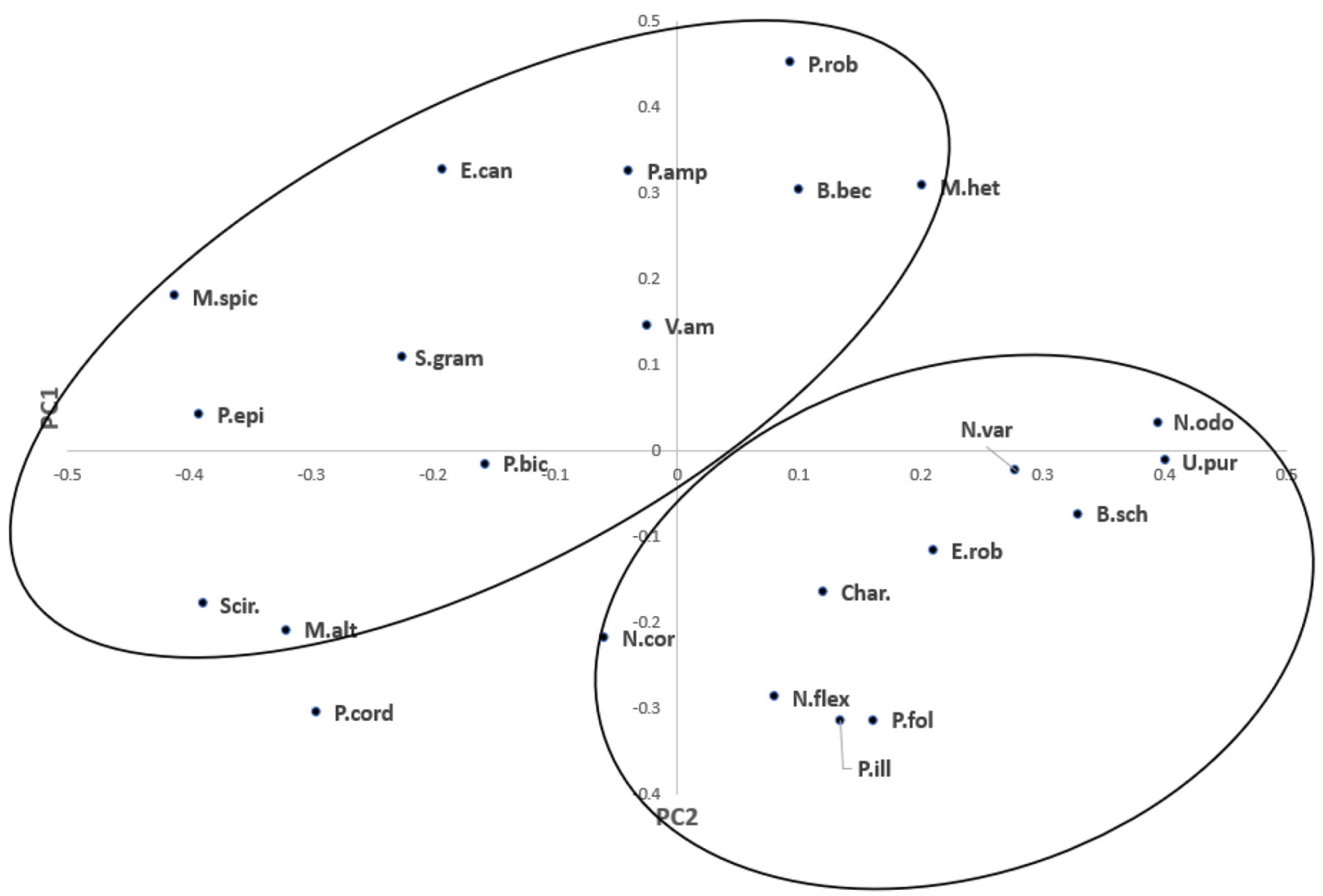

Fig. 2. PCO biplot depicting the proportion present at sampling sites in each lake of all macrophytes sampled (min used in analysis, $N=3$ ). The corresponding species name for the species acronyms are given in Table 3.

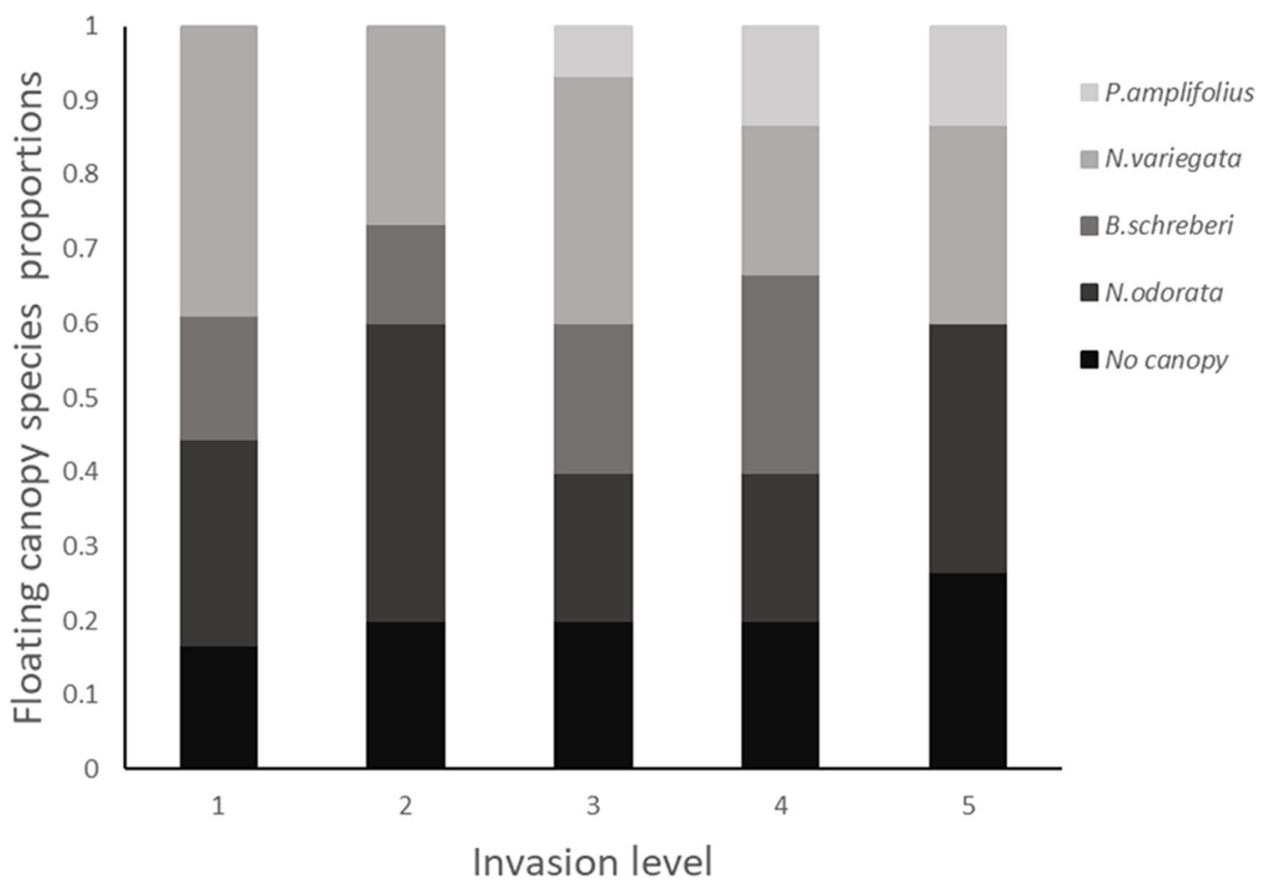

Fig. 3. Bar charts showing frequency of dominance of each floating canopy species the five different invasion intensities. There is little change in dominant canopy types across invasion intensities. The main difference is the appearance of $P$. amplifolius as a dominant canopy species at invasion levels 3,4 , and 5 . 


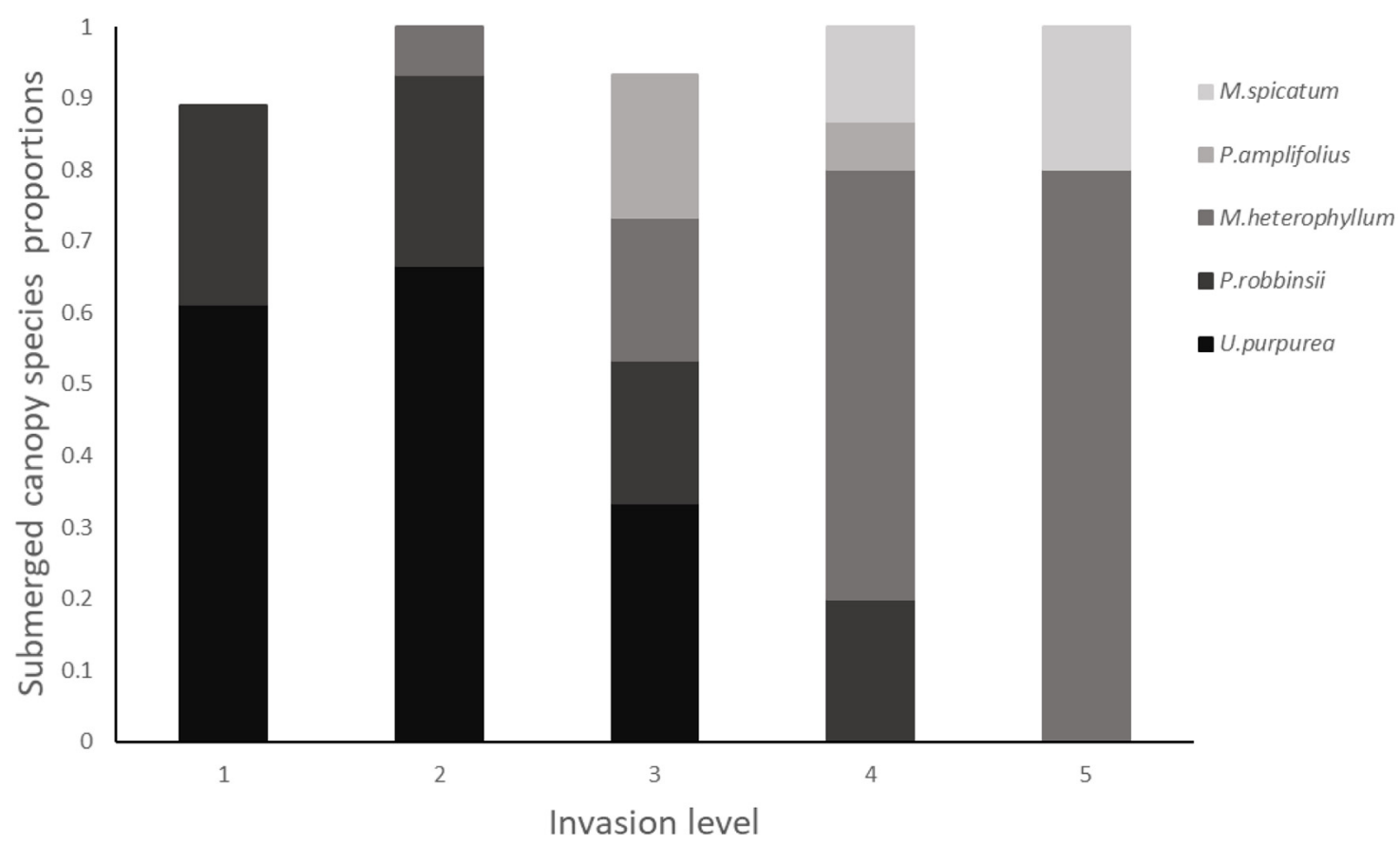

Fig. 4. Bar charts showing frequency of dominance of each submerged canopy species across the five invasion intensities. There is a visually obvious difference in frequency of canopy types at different invasion levels. Invasion levels 1 and 2 are dominated by $P$. robbinsii and $U$. purpurea, while invasion levels 3, 4, and 5 are increasingly dominated by Myriophyllum species, although the native species $P$. amplifolius and $P$. robbinsii persist until invasion level 5 .

Table 4. Pairwise Mann-Whitney tests for OSR under each set of submerged canopy species.

\begin{tabular}{|c|c|c|c|c|c|c|c|c|}
\hline & \multicolumn{2}{|c|}{ M. heterophyllum } & \multicolumn{2}{|c|}{ M. spicatum } & \multicolumn{2}{|c|}{ P. amplifolius } & \multicolumn{2}{|c|}{ P. robbinsii } \\
\hline & $\mathrm{W}$ & $p$ & $\mathrm{~W}$ & $p$ & $\mathrm{~W}$ & $p$ & $\mathrm{~W}$ & $P$ \\
\hline M. spicatum & 322.5 & 0.369 & & & & & & \\
\hline P. amplifolius & 285.0 & 0.404 & 18.5 & 0.118 & & & & \\
\hline P. robbinsii & 437.0 & 0.563 & 50.0 & 0.860 & 48.0 & 0.449 & & \\
\hline U. purpurea & 365.0 & $<0.001^{*}$ & 21.5 & $0.002^{*}$ & 42.0 & 0.226 & 203.0 & $0.002^{*}$ \\
\hline
\end{tabular}

*Indicates significant relationships.

Significance adjusted for ties. M. heterophyllum $n=22$, M. spicatum $n=5$, P. amplifolius $n=4$, P. robbinsii $n=15$, U. purpurea $n=26$.

and invasion levels three $\left(X^{2}=23.633, \mathrm{df}=5, \quad N=20\right.$, $p<0.001)$, four $\left(X^{2}=84.548, \mathrm{df}=5, N=21, p<0.001\right)$, and five $\left(X^{2}=133.262, \mathrm{df}=5, N=21, p<0.001\right)$, demonstrating that invasion intensity did have a significant relationship with submerged canopy structure (Fig. 4).

OSR differed significantly between the submerged canopy species (Kruskal-Wallis, $\mathrm{H}=21.22, \mathrm{df}=5, p=0.001$ ). MannWhitney Pairwise tests (Tab. 4) showed that there was a significant difference in OSR between $M$. heterophyllum $\times$ $U$. purpurea, M. spicatum $\times U$. purpurea, and Potamogeton robbinsii Oakes $\times U$. purpurea. Canopies dominated by $U$. purpurea had the highest OSR (average 8.8 species) and NSR (average 8.2 species). Myriophyllum spicatum had the lowest OSR (average 6.0 species) and NSR (average 5.0 species).

There was also a significant difference in NSR under different submerged canopies (Kruskal-Wallis, $\mathrm{H}=28.36$, $\mathrm{df}=5, p<0.001)$. Pairwise Mann-Whitney tests of differences in NSR between submerged canopy types identified significant differences between $U$. purpurea canopies and almost every other submerged canopy (Tab. 5). P. amplifolius $\times U$. purpurea was not significant (Mann-Whitney $\mathrm{W}=31.0, p=0.0578$ ).

\subsection{Focal species: B. beckii}

Analysis of $B$. beckii was done on data from Lake 1 because $B$. beckii does not appear in Lake 2. It was found most frequently at invasion level 3 (frequency $=0.500$ ) and was most common under a $N$. odorata floating canopy (frequency $=0.500$ ) and a $P$. robbinsii submerged canopy (frequency $=1.000)$. GLM analyses with presence/absence data of $B$. beckii investigated the relationship between this species' presence, invasion intensity, and depth. It was found that $B$. beckii presence cannot be predicted by invasion intensity but is significantly influenced by depth. The presence of this species was positively correlated with depth (GLM, $N=63$; Odds ratio $\mathrm{B}=0.055 ; p=0.004$ ). After 
S. Smith et al.: Knowl. Manag. Aquat. Ecosyst. 2021, 422, 1

Table 5. Mann-Whitney Pairwise tests showing species that have significantly different relationships with NSR.

\begin{tabular}{|c|c|c|c|c|c|c|c|c|}
\hline & \multicolumn{2}{|c|}{ M. heterophyllum } & \multicolumn{2}{|c|}{ M. spicatum } & \multicolumn{2}{|c|}{ P. amplifolius } & \multicolumn{2}{|c|}{ P. robbinsii } \\
\hline & $\mathrm{W}$ & $\mathrm{p}$ & $\mathrm{W}$ & $\mathrm{p}$ & $\mathrm{W}$ & $\mathrm{p}$ & $\mathrm{W}$ & $\mathrm{p}$ \\
\hline M. spicatum & 318.0 & 0.536 & & & & & & \\
\hline P. amplifolius & 281.5 & 0.272 & 18.5 & 0.118 & & & & \\
\hline P. robbinsii & 425.0 & 0.838 & 51.0 & 0.929 & 48.5 & 0.418 & & \\
\hline U. purpurea & 322.0 & $<0.001^{*}$ & 17.0 & $<0.001^{*}$ & 31.0 & 0.058 & 200.0 & $0.002^{*}$ \\
\hline
\end{tabular}

*Indicates significant relationships.

Significance adjusted for ties. M. heterophyllum $n=22$, M. spicatum $n=5$, P. amplifolius $n=4$, P. robbinsii $n=15$, , purpurea $n=26$.

removing depth from the GLM, the relationship with invasion did not change.

\subsection{Focal species: $U$. purpurea}

Analysis of $U$. purpurea was carried out on species presence/absence data from Lake 1 because $U$. purpurea is not present in Lake 2. U. pupurea was found most commonly (frequency $=1.000$ ) at invasion level two, under a floating canopy of $N$. odorata (frequency $=0.864$ ) and a submerged canopy of $M$. heterophyllum (frequency $=0.636)$. The presence patterns of $U$. purpurea were examined with a GLM, which identified invasion level five as a significant negative predictor (GLM, $\mathrm{N}=12$, Odds ratio $\mathrm{B}=-2.364, \mathrm{p}=0.018$ ) of $U$. purpurea presence. No other invasion levels nor depth were significant predictors of $U$. purpurea presence.

\section{Discussion}

\subsection{Methodology}

This study describes a modified portable quadrat that allows for efficient, fine-resolution, low-impact, singleobserver study of submerged macrophyte systems in threedimensional space. This quadrat design is useful for short-term study where installation of a permanent quadrat is impractical. It is non-destructive, thus it is well suited to use in sensitive habitats or, in this case, habitats where disturbance can encourage invasion. Alternate methods such as rake sampling (Buchan and Padilla, 2000) create patches of disturbed ground which milfoil is likely to colonize. We therefore suggest that such non-destructive sampling approaches that consider the three-dimensionality of the aquatic environment should be employed for macrophyte sampling and surveys in lakes. The addition of a meter-ruler on the vertical pole would allow the exact positioning of each sampled macrophyte, if such finescale information is required.

This study also examines the effects of including invasive species in species richness counts, with the impacts on species richness analysed twice, with and without invasive species. The overall conclusions drawn from analysis of these two counts produce different results. A significantly negative impact on species richness was found only when the invasive species were excluded. This is important to note when comparing across studies in invasion ecology literature, as significant impacts of invasive species can be masked by including them in the community analysis.

\subsection{Invasion trends}

The negative relationship between community species richness and increasing invasion intensity adds to the evidence base of negative impact of Myriophyllum species on native communities (Boylen et al., 1996, 1999; Madsen, 1999). A study examining effects of Myriophyllum invasion over time (Boylen et al., 1999) found that species richness declined as the invasion progressed. Other studies have demonstrated that the impact of Myriophyllum on native macrophytes is dependent on the local environmental conditions (Grudnik and Germ, 2013). In the present study, the highest invasion level had a significant negative effect on NSR while no other invasion level did. Some studies have discovered positive relationships of these species with community diversity. These inconsistencies in the literature may come from sampling bias, unexpected ecological relationships, or truly varying relationships of Myriophyllum in different study areas. However, the generally accepted consensus is that invasive Myriophyllum does negatively impact community diversity, and the present study adds support to that claim.

\subsection{Species responses to invasion}

The PCO analysis identified associations of species according to the frequency at which they co-occurred. This analysis provided useful insights when considering the individual species' invasion response. It is evident that some species co-occur with Myriophyllum while others do not. With this information comes the potential for developing indicator species for degree of invasion based on the presence of sensitive/tolerant species. For example, in the Lake 1 system, areas with a higher proportion of $N$. variegata, B. schreberi, and $U$. purpurea were less likely to be heavily invaded. Likewise, areas with high proportions of $P$. amplifolius, E. canadensis, and $P$. robbinsii tended to have higher invasion levels. $P$. robbinsii has shown tolerance to milfoil invasion in other studies (Madsen et al., 1991). This contrasts previous evidence that these three species were negatively affected by milfoil invasion (Boylen et al., 1999). This may be caused by different regions or different sampling techniques but is still noteworthy. It is more difficult to make claims about 
relationships of rarer species (encounter rate of species in Lake 1 is available in Tab. 3).

\subsection{Canopy types}

The use of canopy type as a character of invasion intensity is sparse in the literature with some recent evidence that the presence of native macrophyte species (including canopy species), does not tend to limit the colonisation success of invasive macrophytes (Louback-Franco et al., 2019). This study examines floating and submerged canopy relationships with invasion intensity and overall/native species richness. The results indicate that there is no relationship between floating canopy and invasion intensity. However, there is an effect of submerged canopy on invasion. This is expected as the invasive species examined here are part of the submerged canopy. When examining submerged canopies in a species richness context, patterns emerge. In pairwise tests of the species richness associated with each canopy species, $U$. purpurea stands out as the submerged canopy that harbours significantly more native species richness than the other canopy species. This is supported by the Plant Canopy Hypothesis, which notes that the localized effects of certain aquatic plant species on water chemistry may be pronounced enough to denote areas with different dominant canopies as different habitats (Frodge et al., 1990). As such, the concept of plant canopies should be incorporated into invasion studies more frequently, especially in the study of invasive species that themselves create new chemical environments.

\subsection{Species of conservation interest}

Bidens beckii is a species of interest because it is threatened in Connecticut and therefore its presence can slow down or even prevent active management. In this study, the only significant predictor of this species' presence was depth, not invasion with its abundance being highest at intermediate invasion intensity. This has implications for management. It appears that this species' niche overlaps with that of invasive Myriophyllum, so spot treatment of Myriophyllum beds is not a solution that minimizes impacts on this threatened species. Studies like the present one could be important for informing management of other aquatic systems seeking to manage for both threatened and invasive species.

Utricularia purpurea became a species of interest due to its co-occurrence with high native species richness and low occurrence with invasive species, and in this sense it can be used as an indicator species of fairly pristine macrophyte communities with high species richness and low occurrence of invasive species. A GLM analysis of this species investigating the influence of water depth and invasion intensity identifies the highest invasion level as the greatest predictor of its absence. Capers et al. (2007) note that native species density, not richness, has a negative relationship with invasive species presence. Furthermore, it has also been observed that macrophyte communities with higher species richness overyielded, and thus had better invasion resistance (Petruzzella et al., 2018). The dense mats formed by $U$. purpurea that rarely co-occurred with Myriophyllum in this study could further support this claim. Thus, presence of $U$. purpurea may be an indicator of lower invasion intensity, and its dominance as a canopy type could be used as an indicator of high native species richness.

\section{Conclusion}

The new modified sampling method introduced and used in this study allowed us to collect accurate data on both canopy and well as submerged canopy and subsequently assess impacts of invasive macrophytes separately on each group.

The present study provides support for results of previous studies, confirming the negative effect of invasive Myriophyllum species on native macrophyte communities. It also develops traditional quadrat designs to make singleobserver sampling in fragile macrophyte communities easier, less destructive, and thus potentially more accurate. Species presence patterns reveal community types with different relationships with invasion. Relationships between canopy type and invasion and species richness show potentially useful results for characterizing communities. Some of the most important results come from the examination of species of conservation interest. Co-occurrence of a threatened species with beds of invasive species have implications for management. One submerged canopy species (U. purpurea) may be having significant interactions with invasive species. Further study on the interactions between $U$. purpurea and invasive Myriophyllum is desirable.

\section{Conflict of interest}

The authors declare that they have no conflict of interest.

Acknowledgements. The authors would like to thank the resident communities surrounding the lakes for their tolerance during the field season. They would also like to thank the White Memorial Conservation Center and the Connecticut Agricultural Experiment Station for advice and assistance identifying specimens. We would also like to thank the UK Natural Environment Research Council for their support to FCK (program Oceans 2025-WP 4.5 and grants NE/D521522/1 and NE/J023094/1). This work also received support from the Marine Alliance for Science and Technology for Scotland pooling initiative. MASTS is funded by the Scottish Funding Council (grant reference HR09011) and contributing institutions.

\section{References}

Bernard-Verdier M, Hulme PE. 2015. Alien and native plant species play different roles in plant community structure. $J$ Ecol 103: 143-152.

Bosch I, Makarewicz JC, Bonk EA, Ruiz C, Valentino M. 2009. Responses of lake macrophyte beds dominated by Eurasian watermilfoil (Myriophyllum spicatum) to best management practices in agricultural sub-watersheds: declines in biomass but not species dominance. J Gt Lakes Res 35: 99-108.

Boylen CW, Eichler LW, Sutherland JW. 1996. Physical control of Eurasian watermilfoil in an oligotrophic lake. Hydrobiologia 340: 213-218. 
Boylen CW, Eichler LW, Madsen JD. 1999. Loss of native aquatic plant species in a community dominated by Eurasian watermilfoil. Hydrobiologia 415: 207-211.

Buchan LA, Padilla DK. 2000. Predicting the likelihood of Eurasian watermilfoil presence in lakes, a macrophyte monitoring tool. Ecol Appl 10: 1442-1455.

CAES. 2005. Dog Pond, Goshen.

Capers RS. 2000. A comparison of two sampling techniques in the study of submersed macrophyte richness and abundance. Aquat Bot 68: 87-92.

Capers RS, Selsky R. 2005. West Side Pond- Goshen. Invasive Aquatic Plant Program.

Capers RS, Selsky R, Bugbee GJ, White JC. 2007. Aquatic plant community invasibility and scale-dependent patterns in native and invasive species richness. Ecology 88: 3135-3143.

Eiswerth ME, Donaldson SG, Johnson WS. 2000. Potential environmental impacts and economic damages of Eurasian watermilfoil (Myriophyllum spicatum) in western Nevada and northeastern California. Weed Technol 14: 511-518.

Frodge JD, Thomas GL, Pauley GB. 1990. Effects of canopy formation by floating and submergent aquatic macrophytes on the water quality of two shallow Pacific Northwest lakes. Aquat Bot 38: 231-248.

Gergs R, Rothhaupt K-O. 2015. Invasive species as driving factors for the structure of benthic communities in Lake Constance, Germany. Hydrobiologia 746: 245-254.

Gross EM, Groffier H, Pestelard C, Hussner A. 2020. Ecology and Environmental Impact of Myriophyllum heterophyllum, an Aggressive Invader in European Waterways. Diversity 12: 127.

Grudnik ZM, Germ M. 2013. Spatial pattern of native species Myriophyllum spicatum and invasive alien species Elodea nuttallii after introduction of the latter one into the Drava River (Slovenia). Biologia (Bratisl) 68: 202-209.

Havel JE, Kovalenko KE, Thomaz SM, Amalfitano S, Kats LB. 2015. Aquatic invasive species: challenges for the future. Hydrobiologia 750: $147-170$.

June-Wells M, Hart B. 2012. West Side Pond- Goshen. Invasive Aquatic Plant Program.

Küpper H, Küpper F, Spiller M. 1996. Environmental relevance of heavy metal-substituted chlorophylls using the example of water plants. J Exp Bot 47: 259-266.

Les DH, Mehrhoff LJ. 1999. Introduction of nonindigenous aquatic vascular plants in southern New England: a historical perspective. Biol Invasions 1: 281-300.

Levine JM. 2000. Species diversity and biological invasions: relating local process to community pattern. Science 288: 852-854.

Lichvar RW. 2012. The national wetland plant list. Engineer Research and Development Center Hanover NH Cold Regions Research.

Lockwood JL, Cassey P, Blackburn T. 2005. The role of propagule pressure in explaining species invasions. Trends Ecol Evol 20: 223-228.

Louback-Franco N, Dainez-Filho MS, Souza DC, Thomaz SM. 2019. A native species does not prevent the colonization success of an introduced submerged macrophyte, even at low propagule pressure. Hydrobiologia 847: 1-11.

Louca V, Lindsay SW, Majambere S, Lucas MC. 2009. Fish community characteristics of the lower Gambia River floodplains: a study in the last major undisturbed West African river. Freshw Biol 54: 254-271.

Louca V, Lucas MC, Green C, Majambere S, Fillinger U, Lindsay SW. 2014. Role of fish as predators of mosquito larvae on the floodplain of the Gambia River. J Med Entomol 46: 546-556.

Madsen JD. 1999. Point and line intercept methods for aquatic plant management. APCRP Technical Notes Collection (TN APCRPM1-02). US Army Eng Res Dev Cent Vicksbg MS USA.

Madsen JD, Wersal RM. 2017. A review of aquatic plant monitoring and assessment methods. J Aquat Plant Manag 55: 1-12.

Madsen JD, Sutherland JW, Bloomfield JA, Eichler LW, Boylen CW. 1991. The decline of native vegetation under dense Eurasian watermilfoil canopies. J Aquat Plant Manag 29: 94-99.

Madsen JD, Wersal RM, Woolf TE. 2007. A new core sampler for estimating biomass of submersed aquatic macrophytes. J Aquat Plant Manag 45: 31-34.

Petruzzella A, Manschot J, van Leeuwen CH, Grutters B, Bakker ES. 2018. Mechanisms of invasion resistance of aquatic plant communities. Front Plant Sci 9: 134.

Pimentel D, Zuniga R, Morrison D. 2005. Update on the environmental and economic costs associated with alien-invasive species in the United States. Ecol Econ 52: 273-288.

Qiu X, Mei X, Razlutskij V, Rudstam LG, Liu Z, Tong C, Zhang X. 2019. Effects of common carp (Cyprinus carpio) on water quality in aquatic ecosystems dominated by submerged plants: a mesocosm study. Knowl Manag Aquat Ecosyst 28.

Roberts DW, Roberts MDW. 2016. Package 'labdsv.' Ordination Multivar 775 .

Smith CS, Barko JW. 1990. Ecology of Eurasian watermilfoil. J Aquat Plant Manag 28: 55-64.

Stiers I, Crohain N, Josens G, Triest L. 2011. Impact of three aquatic invasive species on native plants and macroinvertebrates in temperate ponds. Biol Invasions 13: 2715-2726.

Strayer DL. 2010. Alien species in fresh waters: ecological effects, interactions with other stressors, and prospects for the future. Freshw Biol 55: 152-174.

Tan B, He H, Gu J, Li K. 2018. Eutrophic water or fertile sediment: which is more important for the growth of invasive aquatic macrophyte Myriophyllum aquaticum? Knowl Manag Aquat Ecosyst 3

Thum RA, Lennon JT. 2010. Comparative ecological niche models predict the invasive spread of variable-leaf milfoil (Myriophyllum heterophyllum) and its potential impact on closely related native species. Biol Invasions 12: 133.

Van Donk E, Otte A. 1996. Effects of grazing by fish and waterfowl on the biomass and species composition of submerged macrophytes. Hydrobiologia 340: 285-290.

Warton DI, Lyons M, Stoklosa J, Ives AR. 2016. Three points to consider when choosing a LM or GLM test for count data. Methods Ecol Evol 7: 882-890.

Cite this article as: Smith S, Küpper FC, Trinder C, Louca V. 2021. Assessing watermilfoil invasion effects on native macrophyte communities in North American lakes using a novel approach for macrophyte sampling. Knowl. Manag. Aquat. Ecosyst., $422,1$. 